\title{
Low density lipoprotein oxidation by ferritin at lysosomal $\mathrm{pH}$
}

Article

Accepted Version

Ojo, O. O. and Leake, D. S. (2018) Low density lipoprotein oxidation by ferritin at lysosomal $\mathrm{pH}$. Chemistry and Physics of Lipids, 217. pp. 51-57. ISSN 0009-3084 doi:

https://doi.org/10.1016/j.chemphyslip.2018.09.016 Available at https://centaur.reading.ac.uk/80650/

It is advisable to refer to the publisher's version if you intend to cite from the work. See Guidance on citing.

To link to this article DOI: http://dx.doi.org/10.1016/j.chemphyslip.2018.09.016 Publisher: Elsevier

All outputs in CentAUR are protected by Intellectual Property Rights law, including copyright law. Copyright and IPR is retained by the creators or other copyright holders. Terms and conditions for use of this material are defined in the End User Agreement.

\section{www.reading.ac.uk/centaur}

\section{CentAUR}

Central Archive at the University of Reading

Reading's research outputs online 


\title{
Low density lipoprotein oxidation by ferritin at lysosomal $\mathrm{pH}$
}

\author{
Oluwatosin O. Ojo, David S. Leake* \\ School of Biological Sciences and Institute for Cardiovascular and Metabolic Research, University of Reading, \\ Reading, Berkshire, United Kingdom
}

\begin{abstract}
Oxidation of low density lipoprotein (LDL) has been proposed to be involved in the pathogenesis of atherosclerosis. We have previously shown that LDL can be oxidised by iron in lysosomes. As the iron-storage protein ferritin might enter lysosomes by autophagy, we have investigated the ability of ferritin to catalyse LDL oxidation at lysosomal $\mathrm{pH}$. LDL was incubated with ferritin at $37{ }^{\circ} \mathrm{C}$ and $\mathrm{pH}$ 4.5 and its oxidation monitored spectrophotometrically at $234 \mathrm{~nm}$ by the formation of conjugated dienes and by measuring oxidised lipids by HPLC or a tri-iodide assay. Iron released from ferritin was measured using the ferrous iron chelator bathophenanthroline and by ultrafiltration followed by atomic absorption spectroscopy. LDL was oxidised effectively by ferritin $(0.05-0.2 \mu \mathrm{M})$. The oxidation at lysosomal $\mathrm{pH}(\mathrm{pH}$ 4.5) was much faster than at $\mathrm{pH}$ 7.4. Ferritin increased cholesteryl linoleate hydroperoxide, total lipid hydroperoxides and 7-ketocholesterol. Iron was released from ferritin at acidic $\mathrm{pH}$. The iron chelators, diethylenetriaminepentaacetate and EDTA, and antioxidant N,N'-diphenyl-p-phenylenediamine inhibited the oxidation considerably, but not entirely. The antioxidant tempol did not inhibit the initial oxidation of LDL, but inhibited its later oxidation. Cysteamine, a lysosomotropic antioxidant, inhibited the initial oxidation of LDL in a concentrationdependent manner, however, the lower concentrations exhibited a pro-oxidant effect at later times, which was diminished and then abolished as the concentration increased. These results suggest that ferritin might play a role in lysosomal LDL oxidation and that antioxidants that accumulate in lysosomes might be a novel therapy for atherosclerosis.
\end{abstract}

Keywords: Atherosclerosis, Lysosomes, Ferritin, Iron, Cysteamine, LDL oxidation

*Corresponding author at: School of Biological Sciences, Hopkins Building, University of Reading, Whiteknights, Reading, Berkshire, RG6 6UB, United Kingdom.

E-mail address: d.s.leake@ reading.ac.uk (D.S. Leake)

E-mail address:o.o.ojo@pgr.reading.ac.uk (O.O. Ojo)

Abbreviations: BHT, butylated hydroxytoluene: $\mathrm{CLOOH}$, cholesteryl linoleate hydroperoxide; DPPD, $\mathrm{N}, \mathrm{N}^{\prime}$-diphenyl-p-phenylenediamine; DTPA, diethylenetriaminepentaacetic acid; LDL, low density lipoprotein; MOPS, 3-N-morpholinopropanesulphonic acid 


\section{Introduction}

The oxidation of low density lipoprotein (LDL) has been proposed to occur in the extracellular space of the arterial wall and lead to the formation of foam cells and atherosclerosis (Steinberg, 2009). The oxidation of LDL by cells requires the presence of micromolar concentrations of the transition metals copper or iron in the medium (Steinbrecher et al., 1984, Leake and Rankin, 1990). Free copper or iron are not readily available in the plasma or interstitial fluid because they exist in a tightly bound form. A number of mechanisms have been proposed to be involved in the oxidation of LDL in vivo, but at present, there is no consensus on the predominant mechanism by which LDL is modified in vivo. Cultured macrophages have been shown, however, to take up aggregated or acetylated LDL quickly and oxidise it in lysosomes (Wen and Leake, 2007). Cholesterol crystals derived from oxidised LDL in lysosomes have been reported to rupture these organelles in macrophages and activate the NLRP3 inflammasome (Duewell et al., 2010). This might be important as atherosclerosis is a chronic inflammatory disease and can be treated in patients with antibodies against interleukin 1- $\beta$ (Ridker et al., 2017). Foam cells in human atherosclerotic lesions contain ferritin and lysosomal iron (Yuan et al., 1996, Lee et al., 1998, Yuan, 1999). Redox-active iron exists in lysosomes, due to degradation of iron-containing proteins delivered by endocytosis or autophagy, such as ferritin.

The iron hypothesis of atherosclerosis was proposed by Sullivan in 1981 to explain why men get more coronary heart disease than pre-menopausal women because of the higher body iron levels in men (Sullivan, 1981). There are small labile iron pools in cells in the cytosol, mitochondria and lysosomes (Lv and Shang, 2018), with the lysosomal one being of the highest concentration (about 16 $\mu \mathrm{M}$ ) in rat liver endothelial cells (Petrat et al., 2001). Iron is delivered to lysosomes by the autophagocytosis of ferritin or organelles, e.g. mitochondria, and might be released from them by divalent metal transporter 1 ( $\mathrm{Lv}$ and Shang, 2018) Free iron is toxic to the body due to its redox activity and is stored in a tightly bound form that is safe, for instance, in ferritin. Ferritin is made up of 24 polypeptide chains with light (L) subunits and heavy (H) subunits with molecular weights of 19 $\mathrm{kDa}$ and $21 \mathrm{kDa}$ respectively (Theil, 1987, Arosio et al., 2017). Elevated levels of ferritin have been associated with myocardial infarction (Salonen et al., 1992) and there is an increased level of ferritin in atherosclerotic arteries (You et al., 2003). Ferritin and mitochondrial metalloproteins delivered to lysosomes by autophagy are degraded to form low molecular weight iron (Kurz et al., 2007, Lv and Shang, 2018). Some studies have shown that iron from ferritin can be involved in oxidative damage (Reif, 1992). Iron released from transferrin at acidic $\mathrm{pH}$ has been shown to oxidise LDL in vitro (Lamb and Leake, 1994). We now report the ability of ferritin to oxidise LDL effectively at $\mathrm{pH} 4.5$, the $\mathrm{pH}$ of lysosomes (Mindell, 2012), and the effect of antioxidants on this oxidation. 
$\mathrm{N}, \mathrm{N}^{\prime}$-diphenyl-p-phenylenediamine (DPPD), a hydrophobic antioxidant is a potent lipid peroxyl radical scavenger (Tang et al., 2000) and has been shown to inhibit oxidation of LDL (Sparrow et al., 1992, Tangirala et al., 1995, Ahmad and Leake, 2018) and slow down the progression of atherosclerosis (Sparrow et al., 1992, Tangirala et al., 1995). Tempol (4-hydroxy-2,2,6,6tetramethylpiperidine 1-oxyl) has a reducible nitroxide group and is a superoxide dismutase mimetic and can scavenge many reactive oxygen species (Wilcox and Pearlman, 2008).

Our hypothesis is that the major iron-storing protein ferritin can oxidise LDL at lysosomal $\mathrm{pH}$ and we have shown for the first time that it can do so effectively at this $\mathrm{pH}$ and that some antioxidants have surprising complex effects on this oxidation.

\section{Materials and Method}

\subsection{Materials}

All chemicals were purchased from Sigma Aldrich Limited. All ferritin and antioxidant solutions were freshly prepared. Ferritin was from equine spleen with a protein molecular weight of 440 kDa (Sigma Aldrich Limited).

\subsection{LDL Isolation}

LDL was isolated from pooled plasma of two to four healthy volunteers by sequential ultracentrifugation as previously described (Wilkins and Leake, 1994). The LDL was stored at $4{ }^{\circ} \mathrm{C}$ in the presence of $100 \mu \mathrm{M}$ EDTA for up to one month.

\subsection{Measurement of conjugated dienes}

LDL $(50 \mu \mathrm{g}$ protein/ml) was oxidised with ferritin $(0.05 \mu \mathrm{M}-0.2 \mu \mathrm{M})$ in Chelex-100 treated $150 \mathrm{mM} \mathrm{NaCl} / 10 \mathrm{mM}$ sodium acetate buffer $\mathrm{pH} 4.5$ or $150 \mathrm{mM} \mathrm{NaCl} / 10 \mathrm{mM}$ MOPS (3-Nmorpholinopropanesulphonic acid) buffer, $\mathrm{pH}$ 7.4. Chelex-100 is a transition metal chelator and was prewashed in ultrapure water (van Reyk et al., 1995). Formation of conjugated dienes was monitored by measuring attenuance (absorbance plus UV scattering) at $234 \mathrm{~nm}$ at $37{ }^{\circ} \mathrm{C}$ overnight in a dual beam Lamda Bio 40 8-cell position spectrophotometer (PerkinElmer) with UV software (Esterbauer et al., 1989). The test cuvettes were placed against appropriate reference cuvettes which lacked LDL and the attenuance of the reference cuvettes were automatically subtracted from that of the test cuvettes. The initial attenuance was subtracted from later time points.

\subsection{HPLC analysis}


The oxidised lipids in LDL (50 $\mu \mathrm{g}$ protein/ml) oxidised by ferritin $(0.1 \mu \mathrm{M})$ were measured at different times up to $48 \mathrm{~h}$. The oxidation was stopped by adding BHT (butylated hydroxytoluene, dissolved in ethanol; final concentration of BHT $80 \mu \mathrm{M}$ ) and EDTA (final concentration $4 \mathrm{mM}$ ). The samples were analysed by reverse-phase HPLC using a previously described method (Satchell and Leake, 2012).

\subsection{Total hydroperoxide content}

The total hydroperoxides in LDL $(50 \mu \mathrm{g}$ protein/ml $)$ oxidised by ferritin $(0.1 \mu \mathrm{M})$ were measured colourimetrically by a tri-iodide assay (El-Saadani et al., 1989). BHT (final concentration $80 \mu \mathrm{M}$ ) and EDTA (final concentration $4 \mathrm{mM}$ ) were added to stop the oxidation at each time point.

\subsection{Quantification of iron in ferritin}

The amount of iron in ferritin was determined at $248.3 \mathrm{~nm}$ using flame atomic absorption spectroscopy (Analytik JENA AAS NovAA). Samples were prepared according to the method previously described (Herbert et al., 1997).

\subsection{Measurement of iron release from ferritin}

To determine the amount of iron release, ferritin $(0.1 \mu \mathrm{M})$ was incubated at $37{ }^{\circ} \mathrm{C}$ in $\mathrm{NaCl} /$ acetate buffer of $\mathrm{pH} 4.5$ or $\mathrm{NaCl} / \mathrm{MOPS}$ buffer of $\mathrm{pH}$ 7.4. At varying times up to 24 hours samples of $1 \mathrm{ml}$ were taken and the iron chelator bathophenanthroline disulphonic acid $(30 \mu \mathrm{M})$ was added and the amount of ferrous complex formed was measured at $535 \mathrm{~nm}$. $\mathrm{FeSO}_{4}$ was used to construct a standard plot. Iron release was also measured by ultrafiltration using Amicon ultracentrifuge filter tubes $(\mathrm{Mr} 30 \mathrm{kDa}$ ) at $9500 \mathrm{~g}$ for $25 \mathrm{~min}$ followed by atomic absorption spectroscopy (Lamb and Leake, 1994).

\subsection{Data Analysis}

The data were presented as mean and standard error of the mean (SEM) of at least three independent experiments. Comparisons between control and treated samples were analysed by a t-test or one-way-ANOVA with Tukey's post hoc tests. Two-way ANOVA and Bonferroni post-tests were used to compare the data obtained by HPLC and tri-iodide assays. A p value of $<0.05$ was considered statistically significant. 


\section{Results}

\subsection{Ferritin oxidises $L D L$ at lysosomal $\mathrm{pH}$}

To test the ability of ferritin to oxidise LDL at the lysosomal $\mathrm{pH}$ of 4.5 , LDL $(50 \mu \mathrm{g}$ protein/ml) was oxidised in $\mathrm{NaCl} /$ sodium acetate buffer of $\mathrm{pH} 4.5$ at $37{ }^{\circ} \mathrm{C}$ with different concentrations of ferritin $(0.05,0.1$ and $0.2 \mu \mathrm{M}$ in terms of total protein content; horse spleen ferritin with all 24 subunits combined having 440,000 $\mathrm{Da}$ of protein per particle) and the oxidation was monitored by measuring the formation of conjugated dienes at $234 \mathrm{~nm}$. LDL was oxidised effectively by all concentrations of ferritin (Fig. 1A). An aggregation phase where UV scattering occurred followed by a sedimentation phase (where the LDL aggregates fell below the beam of UV in the cuvettes) was then observed. The sedimentation phase occurred at shorter times with the highest concentration of ferritin. These phases are similar to the phases observed with added ferrous or ferric iron (Satchell and Leake, 2012). The oxidation of LDL by ferritin was very much slower at pH 7.4 than $\mathrm{pH} 4.5$ (Fig. 1B).
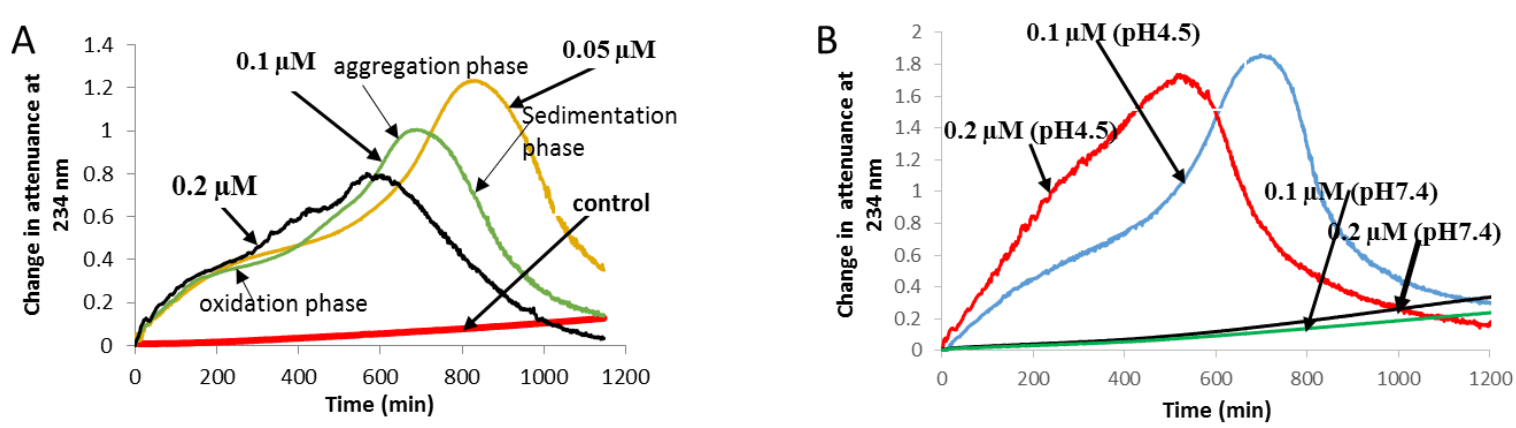

Fig. 1. Effect of ferritin on LDL oxidation. (A) LDL (50 $\mu \mathrm{g}$ protein $/ \mathrm{ml})$ was incubated at $37^{\circ} \mathrm{C}$ in $\mathrm{NaCl} /$ sodium acetate buffer, $\mathrm{pH} 4.5$ in the absence or presence of varying concentrations of ferritin $(0.05 \mu \mathrm{M}$ to $0.2 \mu \mathrm{M})$. Formation of conjugated dienes was monitored by measuring attenuance at 234 $\mathrm{nm}$. (B) LDL (50 $\mu \mathrm{g}$ protein $/ \mathrm{ml}$ ) was incubated with different concentrations of ferritin at $37^{\circ} \mathrm{C}$ in $\mathrm{NaCl} /$ sodium acetate buffer, $\mathrm{pH} 4.5$ or MOPS buffer, $\mathrm{pH}$ 7.4. These results are representative of three independent experiments.

LDL $\left(50 \mu \mathrm{g}\right.$ protein/ml) was incubated with or without ferritin $(0.1 \mu \mathrm{M})$ at $\mathrm{pH} 4.5$ at $37{ }^{\circ} \mathrm{C}$. Cholesteryl linoleate hydroperoxide $(\mathrm{CLOOH})$ and 7-ketocholesterol were generated in the presence of ferritin, but none or very little were formed in its absence (Fig. 2A). As expected (Satchell and Leake, 2012), the fatty acyl moiety of cholesteryl linoleate was oxidised before cholesterol, being more unsaturated. The levels of cholesteryl linoleate hydroperoxide and 7-ketocholesterol at $48 \mathrm{~h}$ were similar to those at $24 \mathrm{~h}$. Total hydroperoxide levels increased with time in the presence of ferritin up to $48 \mathrm{~h}$. 
A

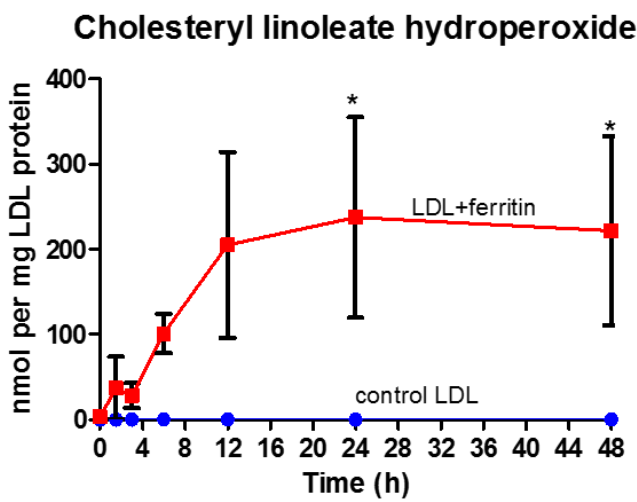

C

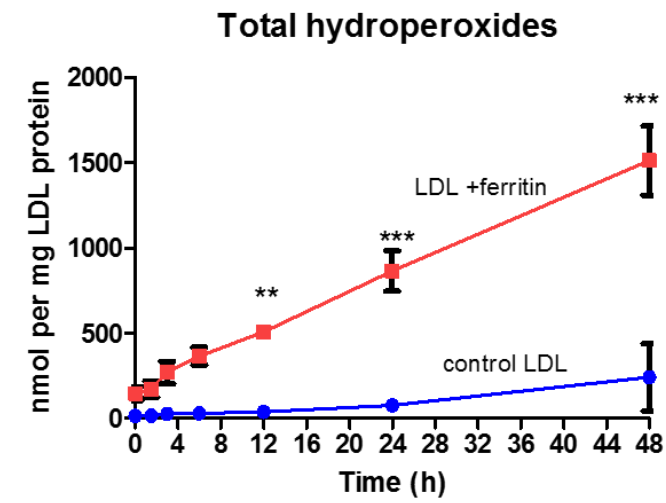

B

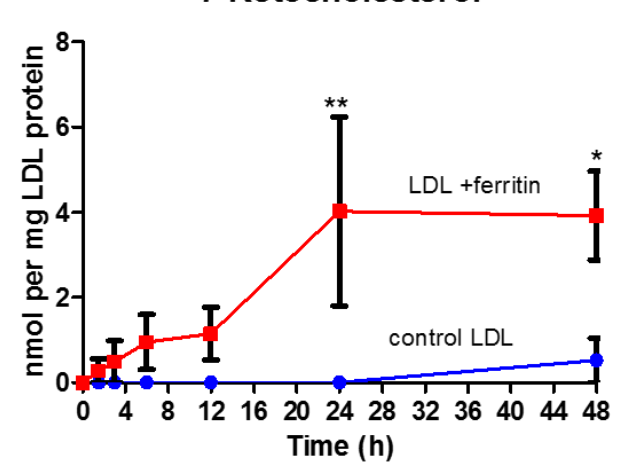

Fig. 2. Oxidised lipids in LDL incubated with ferritin at $\mathrm{pH}$ 4.5. LDL (50 $\mu \mathrm{g}$ protein/ml) was incubated with or without ferritin $(0.1 \mu \mathrm{M})$ in sodium acetate buffer $(\mathrm{pH} 4.5)$ at $37^{\circ} \mathrm{C}$. The samples were assayed for cholesteryl linoleate hydroperoxide (CLOOH) (A) and 7-ketocholesterol (B) by reverse-phase HPLC and for total hydroperoxide content by a tri-iodide assay (C). The mean \pm SEM of three independent experiments are shown. Difference between control LDL and LDL oxidised by ferritin at each time point were determined by two-way ANOVA with Bonferroni post-tests. * indicates $\mathrm{p}<0.05$, ** indicates $\mathrm{p}<0.01, * * *$ indicates $\mathrm{p}<0.001$

\subsection{Iron release from ferritin}

Atomic absorption spectroscopy showed that ferritin particles contained 1001 atoms of Fe. The concentrations of iron contained in the ferritin solutions of $0.05,0.1$, and $0.2 \mu \mathrm{M}$ added in the experiment shown in Fig. 1A were therefore $50 \mu \mathrm{M}, 100 \mu \mathrm{M}$ and $200 \mu \mathrm{M}$. We compared the amount of iron released from ferritin at $\mathrm{pH} 4.5$ and 7.4 to see if this could explain the faster oxidation of LDL observed at $\mathrm{pH} 4.5$. Ferritin $(0.1 \mu \mathrm{M})$ was incubated at $37{ }^{\circ} \mathrm{C}$ in $\mathrm{NaCl} /$ sodium acetate buffer $(\mathrm{pH} 4.5)$ or MOPS buffer ( $\mathrm{pH}$ 7.4) and samples were taken and added to the ferrous iron indicator bathophenanthroline, which does not detect ferric iron (Lynch and Frei, 1995), at different time points 
(Fig. 3A). The amount of ferrous iron released was much higher at $\mathrm{pH} 4.5$ than at $\mathrm{pH} 7.4$. At $24 \mathrm{~h}$, the concentration increased to $15.1 \pm 0.1 \mu \mathrm{M}$ at $\mathrm{pH} 4.5$ out of the total iron present in ferritin of $100 \mu \mathrm{M}$. Ultrafiltration followed by atomic absorption spectroscopy showed the release of $12 \mu \mathrm{M}$ iron at $\mathrm{pH}$ 4.5 and $3.2 \mu \mathrm{M}$ at $\mathrm{pH} 7.4$ at $24 \mathrm{~h}$.

To test the effect of iron chelators, LDL (50 $\mu \mathrm{g}$ LDL protein/ml) was oxidised with $0.1 \mu \mathrm{M}$ ferritin in sodium acetate buffer $(\mathrm{pH} \mathrm{4.5)}$ in the presence or absence of EDTA or DTPA $(100 \mu \mathrm{M})$. Formation of conjugated dienes was monitored (Fig. 3B). The iron chelators inhibited most of the oxidation of LDL, but did not completely inhibit it. This inhibition indicated that the iron release from ferritin was important for the oxidation of LDL.
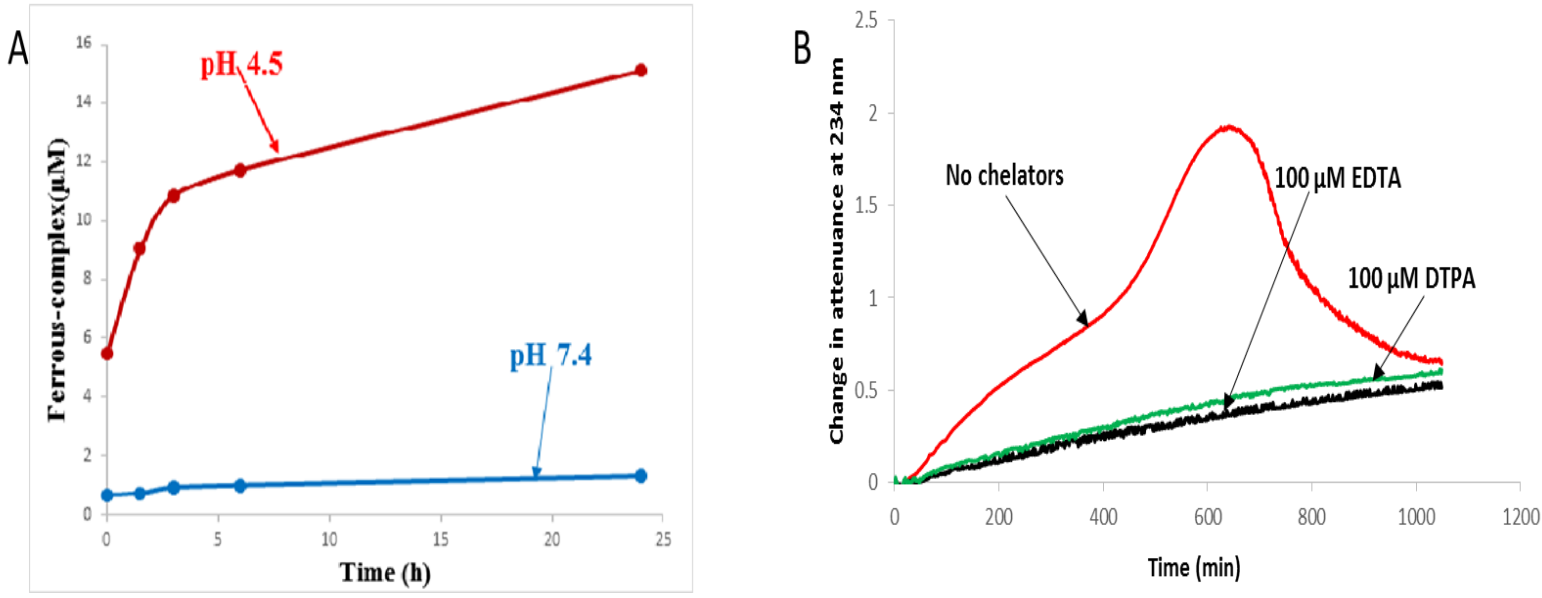

Fig. 3. Determination of iron released from ferritin and effect of iron chelators. (A) Ferritin $(0.1 \mu \mathrm{M})$ was incubated at $37{ }^{\circ} \mathrm{C}$ in $\mathrm{NaCl} / \mathrm{Na}$ acetate buffer ( $\mathrm{pH} 4.5$ ) or MOPS buffer ( $\mathrm{pH}$ 7.4). At different times, a sample $(1 \mathrm{ml})$ was taken and the ferrous chelator bathophenanthroline was added left for 5 min and the absorbance was measured at $535 \mathrm{~nm}$. The means of three independent experiments are shown. (B) LDL $(50 \mu \mathrm{g}$ protein $/ \mathrm{ml})$ was oxidised by ferritin $(0.1 \mu \mathrm{M})$ in sodium acetate buffer $(\mathrm{pH}$ $4.5)$ at $37^{\circ} \mathrm{C}$ in the absence or presence of the iron chelators, EDTA $(100 \mu \mathrm{M})$ and DTPA $(100 \mu \mathrm{M})$. The formation of conjugated dienes was monitored by measuring attenuance at $234 \mathrm{~nm}$. These results are representative of three independent experiments.

\subsection{Effects of antioxidants on LDL oxidation by ferritin at lysosomal $\mathrm{pH}$}

The lipid peroxyl radical scavenger DPPD $(5$ or $10 \mu \mathrm{M})$ greatly inhibited the oxidation of LDL oxidised by ferritin (Fig. 4A), whereas the vehicle ethanol (1\%) had no effect.

The reactive oxygen species scavenger tempol $(10 \mu \mathrm{M})$ did not inhibit the initial oxidation of LDL by ferritin, but inhibited the oxidation later on (Fig. 4B). The inhibition observed at later times 
was sometimes a partial inhibition, as shown in Fig. 4B, or sometimes a total inhibition (results not
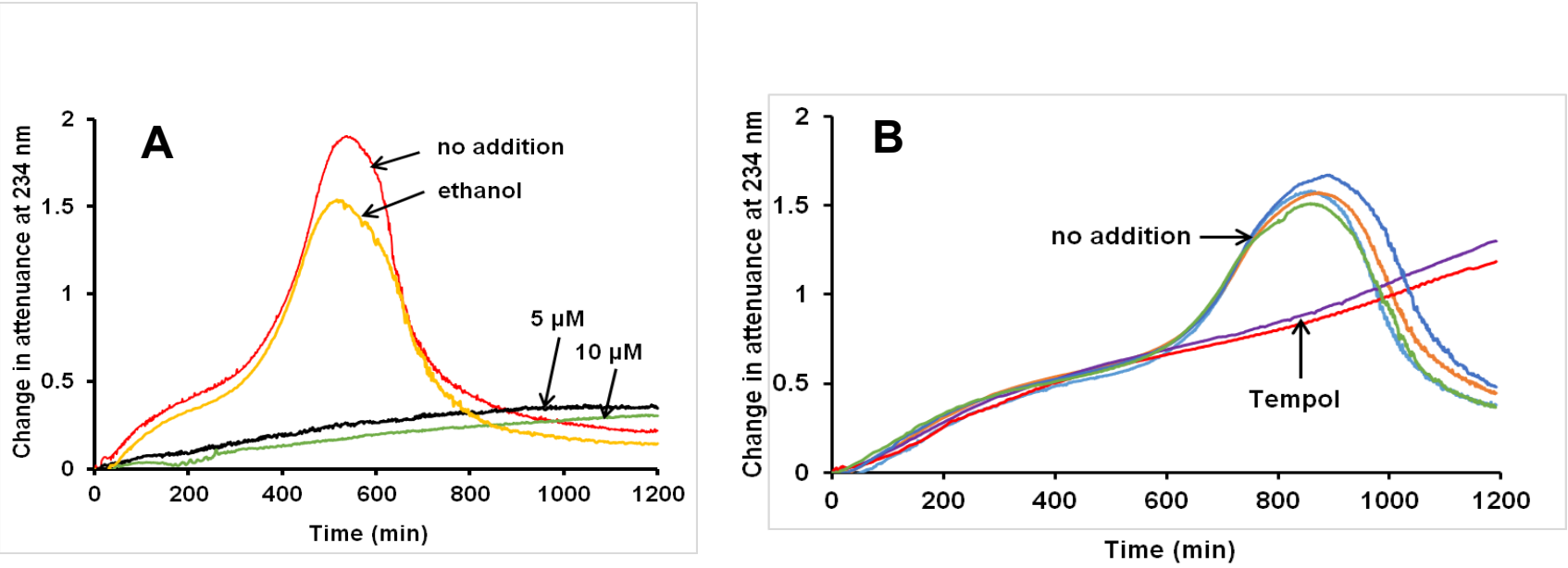

Fig. 4. The effect of DPPD and tempol on LDL oxidation by ferritin. LDL was incubated with ferritin $(0.1 \mu \mathrm{M})$ at $\mathrm{pH} 4.5$ in the presence of (A) DPPD $(5$ or10 $\mu \mathrm{M})$ or ethanol $(1 \% \mathrm{v} / \mathrm{v})$ as a control or (B) tempol $(10 \mu \mathrm{M})$ in duplicate or without additions in quadruplicate. These results are representative of three independent experiments for DPPD and were replicated six times for tempol. Tempol did not inhibit the early oxidation in all six experiments, but inhibited the later oxidation substantially but partially, as shown here, in three experiments or totally in three experiments.

Cysteamine (2-aminoethanethiol) is an antioxidant which concentrates in lysosomes and is used to treat the rare lysosomal storage disease cystinosis in which cysteine accumulates in lysosomes (Dohil et al., 2010). The plasma concentration of cysteamine in treated patients is about $40 \mu \mathrm{M}$ (Bouazza et al., 2011). It should accumulate by several orders of magnitude in lysosomes by proton trapping of its amine group due to the acidic pH in the lysosomes (Pisoni et al., 1995). Cysteamine had a complex, but consistent, effect on the kinetics of LDL oxidation. Cysteamine slowed down the initial oxidation of LDL by ferritin in a concentration-dependent manner (Fig. 5A). At later time points, cysteamine increased the rate of oxidation of LDL so that it overtook the oxidation of the control LDL, with the greatest effect seen with 25-100 $\mu \mathrm{M}$ cysteamine. Higher concentrations of cysteamine did not increase the rate of oxidation as much. All cysteamine concentrations decreased the time taken to attain maximum attenuance, except for $1 \mathrm{mM}$ and above. High concentrations of cysteamine ( $3 \mathrm{mM}-10 \mathrm{mM}$ ) greatly inhibited the oxidation of LDL at all studied time points (Fig. 5B). Ferritin was incubated for up to $24 \mathrm{~h}$ with $25 \mu \mathrm{M}$ (Fig. 5C) or $1 \mathrm{mM}$ (Fig. 5D) cysteamine and samples were taken and the ferrous iron indicator bathophenantroline was added and the absorbance at $535 \mathrm{~nm}$ measured after $5 \mathrm{~min}$. Both concentrations of cysteamine increased ferrous iron release from ferritin to a similar extent compared to the control. The release was rapidly at first and more slowly later. About $30 \%$ of the iron in ferritin was released in $24 \mathrm{~h}$. 

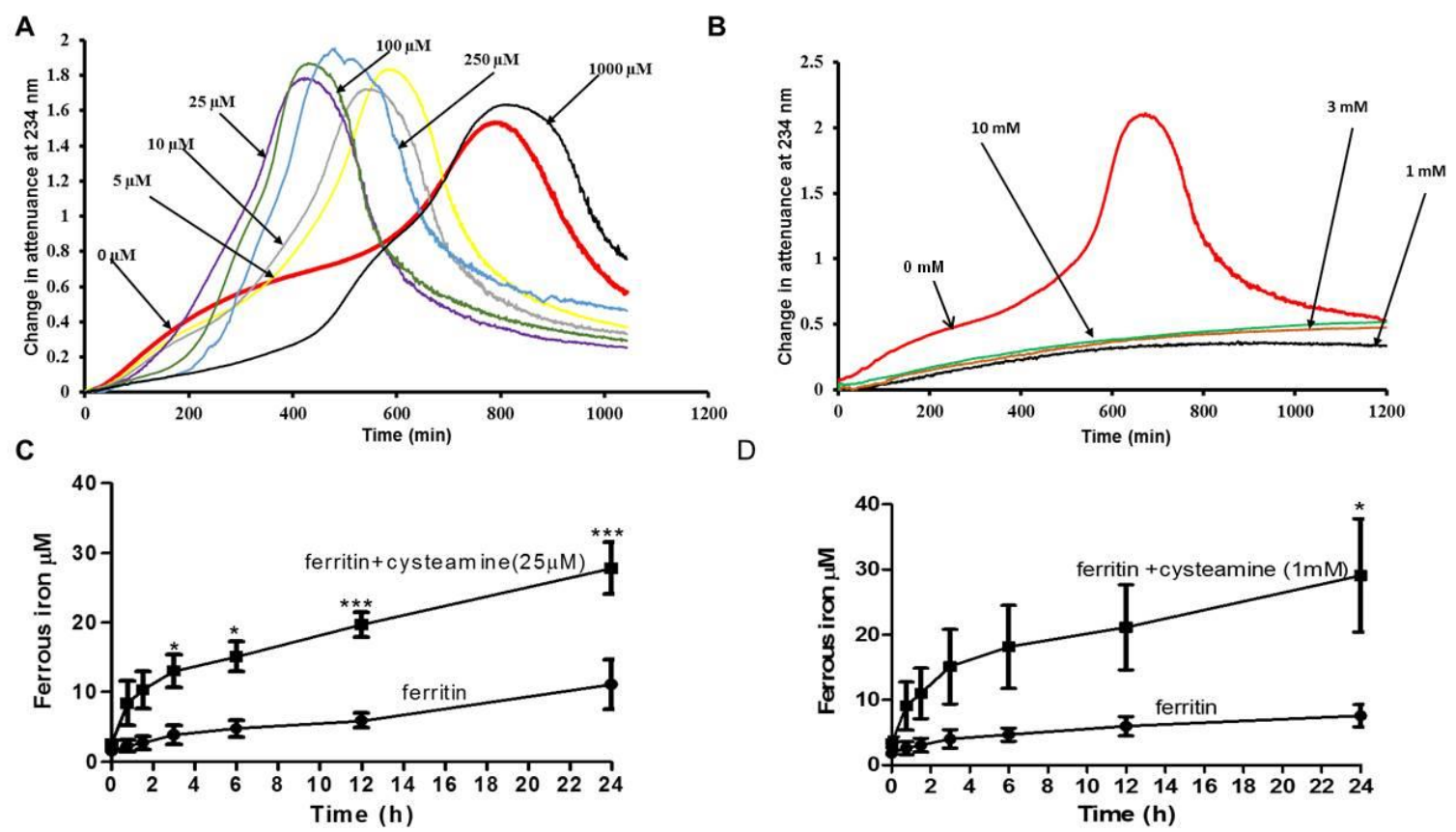

Fig. 5. The effect of cysteamine on LDL oxidation by ferritin. LDL ( $50 \mu \mathrm{g}$ protein $/ \mathrm{ml})$ was oxidised with ferritin $(0.1 \mu \mathrm{M})$ in sodium acetate buffer $(\mathrm{pH} 4.5)$ at $37{ }^{\circ} \mathrm{C}$ with $5-1000 \mu \mathrm{M}(\mathrm{A})$ or $1-10 \mathrm{mM}$ (B) cysteamine. The formation of conjugated dienes was monitored by measuring attenuance at 234 $\mathrm{nm}$. For the colour version of (A), the colours of the lines correspond to the concentrations of cysteamine as follows: red 0 , yellow 5 , grey 10 , purple 25 , green 100 , blue 250 and black $1,000 \mu \mathrm{M}$. For (B), the colours of the lines correspond to the concentrations of cysteamine as follows: red 0 , black 1, brown 3 and green $10 \mathrm{mM}$. Ferritin $(0.1 \mu \mathrm{M})$ was incubated at $37{ }^{\circ} \mathrm{C}$ in $\mathrm{NaCl} / \mathrm{Na}$ acetate buffer $(\mathrm{pH} 4.5)$ in the absence or presence of cysteamine $(25 \mu \mathrm{M})(\mathrm{C})$ or $1 \mathrm{mM}$ (D). At different times, a sample $(1 \mathrm{ml})$ was taken and the ferrous chelator bathophenanthroline was added, left for 5 min and the absorbance was measured at $535 \mathrm{~nm}$ (* indicates $\mathrm{p}<0.05$, *** indicates $\mathrm{p}<0.001)$. These results are representative of three independent experiments

\section{Discussion}

The iron hypothesis of atherosclerosis has been supported indirectly by the availability of redox-active iron and high levels of both the $\mathrm{L}$ and $\mathrm{H}$ subunits of the iron storage protein ferritin in atherosclerotic lesions (Smith et al., 1992, Pang et al., 1996, You et al., 2003). Ferritin levels are increased by cytokines (Miller et al., 1991) and high levels of iron (Casey et al., 1988), which are present in atherosclerotic lesions. Ferritin might be delivered to lysosomes by autophagy of cytosolic ferritin or by other mechanisms (Asano et al., 2011). Redox-active iron in the lysosomes may play a key role in lysosomal LDL oxidation (Wen and Leake, 2007, Satchell and Leake, 2012). This present study was designed to explore the possible involvement of ferritin in lysosomal LDL oxidation and the effects of antioxidants on this oxidation. 
LDL was oxidised effectively at all concentrations of ferritin at $\mathrm{pH} 4.5$ and caused large scale aggregation of the oxidised LDL (Fig. 1A). The oxidation of LDL by ferritin was much faster at acidic $\mathrm{pH}$ (Fig 1B). Oxidation of LDL by ferrous ions was previously demonstrated to be much faster at acidic $\mathrm{pH}$ (Wen and Leake, 2007, Satchell and Leake, 2012) than $\mathrm{pH} 7.4$, the $\mathrm{pH}$ of normal plasma and interstitial fluid. The measurement of cholesteryl linoleate hydroperoxide and 7-ketocholesterol by HPLC and total hydroperoxides by a tri-iodide assay confirmed the oxidation of LDL by ferritin (Fig. 2). The total hydroperoxides continued to increase after $24 \mathrm{~h}$, whereas the cholesteryl linoleate hydroperoxide did not increase after $24 \mathrm{~h}$ possibly because the phospholipids oxidised more slowly than the cholesteryl esters or the cholesteryl linoleate hydroperoxide was further oxidised and emerged from the HPLC column at a different time as an unidentified peak of a different mass.

A previous study has shown that release of iron from ferritin requires lysosomal acidity and protease activity (Kidane et al., 2006), although there would have been no protease activity in our system. The increased oxidation of LDL by ferritin was due to the release of iron from the ferritin core as shown by the ferrous iron chelator bathophenanthroline (Fig. 3A) or ultrafiltration followed by measuring the released iron using atomic absorption spectroscopy. We detected very few degradation products in ferritin incubated alone at $\mathrm{pH} 4.5$ when analysed by SDS-polyacrylamide gel electrophoresis (unpublished results). Our finding that ferritin releases iron spontaneously at lysosomal $\mathrm{pH}$ without proteolysis has relevance to the normal physiology of ferritin degradation and iron acquisition by the cell.

Fully saturated ferritin has the capacity to store up to 4500 atoms of iron per particle. We determined that the ferritin from equine spleen used in these experiments contained 1000 atoms of iron per particle and the concentration of ferritin typically used in our experiments, $0.1 \mu \mathrm{M}$, therefore contained $100 \mu \mathrm{M}$ of iron. The rapid oxidation of LDL at lysosomal pH (Fig 1) could be attributed to the release of ferrous iron $\left(\mathrm{Fe}^{2+}\right)$ at this $\mathrm{pH}$. The release of iron was rapid at first and much slower later (Fig. 3A). About 15\% of the iron contained in ferritin was released at lysosomal pH over $24 \mathrm{~h}$, but very little was released at $\mathrm{pH} 7.4$, as shown by a ferrous iron assay using bathophenanthroline (Fig. 3A) and atomic absorption spectroscopy. The immediate formation of a ferrousbathophenantroline complex may be due to loosely bound iron in the core of ferritin that had already been released from the ferritin particles or to iron associated with ferritin which bathophenanthroline was able to bind. It is not known why iron release was faster at acidic $\mathrm{pH}$, but iron is much more soluble at acidic $\mathrm{pH}$ and it might be speculated that an acidic $\mathrm{pH}$ opened the pores in the surface of ferritin through which iron is released (Jin et al., 2001).

The iron chelator DTPA completely inhibits the oxidation of LDL catalysed by ferrous iron at acidic pH (Satchell and Leake, 2012). Both DTPA and EDTA inhibited LDL oxidation by ferritin to a large extent, but not entirely (Fig. 3B). This might imply that in addition to the iron release, 
reactive oxygen species are formed from inside the ferritin particles which can oxidise LDL. The ferrous iron released from ferritin can react with molecular oxygen to produce the superoxide radical $\left(\mathrm{O}_{2}-\right)$ (eqn 1) which can protonate at acidic $\mathrm{pH}$ to form the hydroperoxyl radical $\left(\mathrm{HO}_{2}\right)$

$$
\begin{array}{ll}
\mathrm{Fe}^{2+}+\mathrm{O}_{2} \rightarrow \mathrm{Fe}^{3+}+\mathrm{O}_{2--}^{--} & \text {eqn } 1 \\
\mathrm{O}_{2}{ }^{--}+\mathrm{H}^{+} \rightarrow \mathrm{HO}_{2} \cdot & \text { pKa }_{\mathrm{a}} 4.8 \text { eqn } 2
\end{array}
$$

Hydroperoxyl radicals are much more reactive than superoxide radicals in oxidising LDL (Bedwell et al., 1989). Hydroperoxyl radicals can abstract a bisallylic hydrogen atom from a polyunsaturated fatty acyl group in a lipid in LDL to form lipid radicals (eqn 3-6).

$$
\begin{array}{ll}
\mathrm{LH}+\mathrm{HO}_{2} \cdot \mathrm{L}^{+}+\mathrm{H}_{2} \mathrm{O}_{2} & \text { eqn } 3 \\
\mathrm{~L}^{+}+\mathrm{O}_{2} \rightarrow \mathrm{LOO}^{-} & \text {eqn } 4 \\
\mathrm{LOO}+\mathrm{LH}^{\prime} \rightarrow \mathrm{LOOH}+\mathrm{L}^{\prime} & \text { eqn } 5 \text { (chain reaction) } \\
\mathrm{LOOH}+\mathrm{Fe}^{2+} \rightarrow \mathrm{LO}^{\cdot}+\mathrm{OH}^{-}+\mathrm{Fe}^{3+} & \text { eqn } 6
\end{array}
$$

LDL oxidation by ferritin might therefore be much faster at acidic $\mathrm{pH}$ because (1) iron is released from ferritin much faster at acidic $\mathrm{pH}$ and (2) highly reactive hydroperoxyl radicals are formed at acidic $\mathrm{pH}$.

DPPD effectively inhibits oxidation of LDL by copper and endothelial cells at $\mathrm{pH} 7.4$ (Sparrow et al., 1992) and by ferrous iron at pH 4.5 (Ahmad and Leake, 2018). It also protects against atherosclerosis in cholesterol-fed rabbits (Sparrow et al., 1992) and decreases atherosclerosis in apoE deficient mice (Tangirala et al., 1995). In this present study DPPD, a secondary amine antioxidant, greatly reduced the formation of conjugated dienes in LDL oxidised by ferritin (Fig. 4A). Its hydrophobic nature might make it a highly effective antioxidant, as it would be expected to scavenge radicals formed within the core of LDL. Its ability to inhibit LDL oxidation by ferritin at lysosomal pH might help to explain why it decreased atherosclerosis in animal models (Sparrow et al., 1992, Tangirala et al., 1995). DPPD cannot be used in humans, however, because it is mutagenic (Sofuni et al., 1990).

Tempol is a nitroxide compound which scavengers reactive oxygen species and is a superoxide dismutase mimetic (Wilcox and Pearlman, 2008). Unexpectedly, it did not inhibit the initial oxidation of LDL by ferritin at $\mathrm{pH} 4.5$, but inhibited the oxidation at later times, always substantially (Figure 4B) and sometimes totally. Tempol is an amphipathic compound and might be expected to accumulate in the phospholipid outer monolayer of LDL, rather than in its cholesteryl ester core. We suspect the oxidation of LDL by iron at lysosomal pH starts in the core of LDL and then spreads to the phospholipid monolayer (Ahmad and Leake, 2018). Tempol might not be able to 
scavenge superoxide or hydroperoxyl radicals effectively enough to stop them entering the LDL particles and oxidising its core, but might be able to inhibit the later oxidation of the phospholipid monolayer by scavenging phospholipid peroxyl or alkoxyl radicals.

Cysteamine contains a thiol group and effectively inhibits the oxidation of LDL by ferrous iron at lysosomal $\mathrm{pH}$ (Ahmad and Leake, 2018). Thiols have previously been seen to act as promoters (Heinecke et al., 1993) or inhibitors of LDL oxidation (Patterson et al., 2003). Cysteamine at concentrations up to $250 \mu \mathrm{M}$ initially protected LDL from oxidation by ferritin in a concentrationdependent manner (Fig. 5A). The antioxidant effect might possibly be due to the lower availability of iron, as cysteamine might possibly be able to bind to and inactivate iron released from ferritin. It might also be scavenging hydroperoxyl radicals and superoxide radicals (equations 9 and 10).

$$
\begin{array}{lc}
\mathrm{HO}_{2}+\mathrm{NH}_{2} \mathrm{CH}_{2} \mathrm{CH}_{2} \mathrm{SH} \rightarrow \mathrm{H}_{2} \mathrm{O}_{2}+\mathrm{NH}_{2} \mathrm{CH}_{2} \mathrm{CH}_{2} \mathrm{~S} & \text { eqn } 9 \\
\mathrm{O}_{2}{ }^{-}+\mathrm{NH}_{2} \mathrm{CH}_{2} \mathrm{CH}_{2} \mathrm{SH}+\mathrm{H}^{+} \rightarrow \mathrm{H}_{2} \mathrm{O}_{2}+\mathrm{NH}_{2} \mathrm{CH}_{2} \mathrm{CH}_{2} \mathrm{~S} & \text { eqn } 10
\end{array}
$$

A pro-oxidant effect was observed at later times (Fig. 5A) in that the rate of oxidation increased and overtook the oxidation of LDL incubated without cysteamine. The pro-oxidant effect was probably due to cysteamine removing iron from ferritin (Fig. 5C \& 5D), as it might reduce ferric ion $\left(\mathrm{Fe}^{3+}\right)$ in ferritin to ferrous ion $\left(\mathrm{Fe}^{2+}\right)($ eqn 11$)$.

$$
\mathrm{NH}_{2} \mathrm{CH}_{2} \mathrm{CH}_{2} \mathrm{SH}+\mathrm{Fe}^{3+} \rightarrow \mathrm{NH}_{2} \mathrm{CH}_{2} \mathrm{CH}_{2} \mathrm{~S}+\mathrm{H}^{+}+\mathrm{Fe}^{2+}
$$

eqn 11

The $\mathrm{Fe}^{2+}$ formed might cause the generation of superoxide radicals $\left(\mathrm{O}_{2}-{ }^{-}\right)$and hydroperoxyl radicals $\left(\mathrm{HO}_{2}\right)$ by equations 1 and 2 . The $\mathrm{Fe}^{2+}$ might also decompose lipid hydroperoxides (eqn 6) far faster than would $\mathrm{Fe}^{3+}$ (Esterbauer et al., 1992). The pro-oxidant and antioxidant effects of cysteamine might depend on its concentration in differing ways and this might explain the complex kinetics. As the concentration of cysteamine increased from low to moderate concentrations, the pro-oxidant effect increased, but at high concentrations, the antioxidant effects of cysteamine predominated (Fig. 5B). Plasma cysteamine concentrations of about $40 \mu \mathrm{M}$ are found in cystinosis patients (Bouazza et al., 2011). Cysteamine can accumulate in lysosomes due to ion trapping of its amine group (Pisoni et al., 1995) and so millimolar concentrations of cysteamine might be present in these organelles, which might inhibit the oxidation of LDL to a large extent.

These findings show that LDL can be oxidised by iron released from ferritin at lysosomal $\mathrm{pH}$ and raise the possibility that ferritin is a major source of iron in lysosomes that contributes to LDL oxidation in atherosclerosis. This oxidation was inhibited greatly by high concentrations of the lysosomotropic drug cysteamine, which is already used in patients for the rare lysosomal storage disease cystinosis. Lysosomal dysfunction might well play an important role in atherosclerosis (Jerome, 2010, Emanuel et al., 2014). The inhibition of lysosomal LDL oxidation by lysosomotropic antioxidants therefore raises a novel therapeutic possibility for atherosclerosis. It is interesting that 
there is a strong inverse relationship between the number of years that cystinosis patients have taken cysteamine and arterial calcification (Ueda et al., 2006).

\section{Conflict of interest}

The authors declare that they do not have anything to disclose regarding conflict of interest with respect to this manuscript.

\section{Authors contributions}

O.O.O. performed the experiments and O.O.O. and D.S.L. designed the study and wrote the manuscript.

\section{Acknowledgments}

We are grateful to Tertiary Education Trust Fund (TETFund) for sponsorship of O.O.O. We thank

Chris J. Humphrey for setting up the atomic absorption spectrophotometer, our colleagues who volunteered to donate blood for LDL isolation and Dr Kim G. Jackson and Ms Rada G. Mihaylova for skilfully taking blood.

\section{References}

Ahmad, F. \& Leake, D. S., 2018. Antioxidants inhibit low density lipoprotein oxidation less at lysosomal $\mathrm{pH}$ : A possible explanation as to why the clinical trials of antioxidants might have failed. Chem. Phys. Lipids 213, 13-24.

Arosio, P., Elia, L. \& Poli, M., 2017. Ferritin, cellular iron storage and regulation. IUBMB Life 69, 414422.

Asano, T., Komatsu, M., Yamaguchi-Iwai, Y., Ishikawa, F., Mizushima, N. \& Iwai, K., 2011. Distinct mechanisms of ferritin delivery to lysosomes in iron-depleted and iron-replete cells. Mol. Cell. Biol. 31, 2040-2052.

Bedwell, S., Dean, R. T. \& Jessup, W., 1989. The action of defined oxygen-centered free radicals on human low-density lipoprotein. Biochem. J. 262, 707-712.

Bouazza, N., Treluyer, J. M., Ottolenghi, C., Urien, S., Deschenes, G., Ricquier, D., Niaudet, P. \& Chadefaux-Vekemans, B., 2011. Population pharmacokinetics and pharmacodynamics of cysteamine in nephropathic cystinosis patients. Orphanet J. Rare Dis. 6, 86.

Casey, J. L., Hentze, M. W., Koeller, D. M., Caughman, S. W., Rouault, T. A., Klausner, R. D. \& Harford, J. B., 1988. Iron-responsive elements: regulatory RNA sequences that control mRNA levels and translation. Science, 240, 924-8.

Dohil, R., Gangoiti, J. A., Cabrera, B. L., Fidler, M., Schneider, J. A. \& Barshop, B. A., 2010. Long-term treatment of cystinosis in children with twice-daily cysteamine. J. Pediatrics 156, 823-827.

Duewell, P., Kono, H., Rayner, K. J., Sirois, C. M., Vladimer, G., Bauernfeind, F. G., Abela, G. S., Franchi, L., Nunez, G., Schnurr, M., Espevik, T., Lien, E., Fitzgerald, K. A., Rock, K. L., Moore, K. J., Wright, S. D., Hornung, V. \& Latz, E., 2010. NLRP3 inflammasomes are required for atherogenesis and activated by cholesterol crystals. Nature 464, 1357-U7.

El-Saadani, M., Esterbauer, H., El-Sayed, M., Goher, M., Nassar, A. Y. \& Jürgens, G., 1989. A spectrophotometric assay for lipid peroxides in serum lipoproteins using a commercially available reagent. J. Lipid Res. 30, 627-630. 
Emanuel, R., Sergin, I., Bhattacharya, S., Turner, J. N., Epelman, S., Settembre, C., Diwan, A., Ballabio, A. \& Razani, B., 2014. Induction of lysosomal biogenesis in atherosclerotic macrophages can rescue lipid-induced lysosomal dysfunction and downstream sequelae. Arterioscler. Thromb. Vasc. Biol. 34, 1942-1952.

Esterbauer, H., Gebicki, J., Puhl, H. \& Jürgens, G., 1992. The role of lipid peroxidation and antioxidants in oxidative modification of LDL. Free Radic. Biol. Med. 13, 341-390.

Esterbauer, H., Striegl, G., Puhl, H. \& Rotheneder, M., 1989. Continuous monitoring of in vitro oxidation of human low density lipoprotein. Free Radic. Res. Commun. 6, 67-75.

Heinecke, J. W., Kawamura, M., Suzuki, L. \& Chait, A., 1993. Oxidation of low-density-lipoprotein by thiols - superoxide-dependent and superoxide-independent mechanisms. J. Lipid Res. 34, 2051-2061.

Herbert, V., Jayatilleke, E., Shaw, S., Rosman, A. S. \& Giardina, P., 1997. Serum ferritin iron, a new test, measures human body iron stores unconfounded by inflammation. Stem Cells 15, 291296.

Jerome, W. G., 2010. Lysosomes, cholesterol and atherosclerosis. Clin. Lipidol. 5, 853-865.

Jin, W., Takagi, H., Pancorbo, B. \& Theil, E. C., 2001. "Opening" the ferritin pore for iron release by mutation of conserved amino acids at interhelix and loop sites. Biochemistry 40, 7525-32.

Kidane, T. Z., Sauble, E. \& Linder, M. C., 2006. Release of iron from ferritin requires lysosomal activity. Am. J. Physiol. Cell Physiol. 291, C445-C455.

Kurz, T., Terman, A. \& Brunk, U. T., 2007. Autophagy, ageing and apoptosis: The role of oxidative stress and lysosomal iron. Arch. Biochem. Biophys. 462, 220-230.

Lamb, D. J. \& Leake, D. S., 1994. Iron released from transferrin at acidic $\mathrm{pH}$ can catalyse the oxidation of low density lipoprotein. FEBS Lett. 352, 15-18.

Leake, D. S. \& Rankin, S. M., 1990. The oxidative modification of low-density lipoproteins by macrophages. Biochem. J. 270, 741-748.

Lee, F. Y., Lee, T. S., Pan, C. C., Huang, A. L. \& Chau, L. Y., 1998. Colocalization of iron and ceroid in human atherosclerotic lesions. Atherosclerosis 138, 281-288.

Lv, H. H. \& Shang, P., 2018. The significance, trafficking and determination of labile iron in cytosol, mitochondria and lysosomes. Metallomics 10, 899-916.

Lynch, S. M. \& Frei, B., 1995. Reduction of copper, but not iron, by human low density lipoprotein (LDL) - implications for metal ion-dependent oxidative modification of LDL. J. Biol. Chem. 270, 5158-5163.

Miller, L. L., Miller, S. C., Torti, S. V., Tsuji, Y. \& Torti, F. M., 1991. Iron-independent induction of ferritin-H chain by tumor necrosis factor. Proc. Natl. Acad. Sci. U. S. A. 88, 4946-4950.

Mindell, J. A., 2012. Lysosomal acidification mechanisms. Annu. Rev. Physiol. 74, 69-86.

Pang, J. H. S., Jiang, M. J., Chen, Y. L., Wang, F. W., Wang, D. L., Chu, S. H. \& Chau, L. Y., 1996. Increased ferritin gene expression in atherosclerotic lesions. J. Clin. Invest. 97, 2204-2212.

Patterson, R. A., Lamb, D. J. \& Leake, D. S., 2003. Mechanisms by which cysteine can inhibit or promote the oxidation of low density lipoprotein by copper. Atherosclerosis 169, 87-94.

Petrat, F., De Groot, H. \& Rauen, U., 2001. Subcellular distribution of chelatable iron: a laser scanning microscopic study in isolated hepatocytes and liver endothelial cells. Biochem. J. 356, 61-69.

Pisoni, R. L., Park, G. Y., Velilla, V. Q. \& Thoene, J. G., 1995. Detection and characterization of a transport systm mediating cysteamine entry into human fibroblast lysosomes - Specificity for aminoethylthiol and aminoethylsulfide derivavtives. J. Biol. Chem. 270, 1179-1184.

Reif, D. W., 1992. Ferritin as a source of iron for oxidative damage. Free Radic. Biol. Med. 12, 417427.

Ridker, P. M., Everett, B. M., Thuren, T., Macfadyen, J. G., Chang, W. H., Ballantyne, C., Fonseca, F., Nicolau, J., Koenig, W., Anker, S. D., Kastelein, J. J. P., Cornel, J. H., Pais, P., Pella, D., Genest, J., Cifkova, R., Lorenzatti, A., Forster, T., Kobalava, Z., Vida-Simiti, L., Flather, M., Shimokawa, H., Ogawa, H., Dellborg, M., Rossi, P. R. F., Troquay, R. P. T., Libby, P., Glynn, R. J. \& Grp, C. T., 
2017. Antiinflammatory therapy with canakinumab for atherosclerotic disease. New Engl. J. Med. 377, 1119-1131.

Salonen, J. T., Nyyssonen, K., Korpela, H., Tuomilehto, J., Seppanen, R. \& Salonen, R., 1992. High stored iron levels are associated with excess risk of myocardial infarction in eastern Finnish men. Circulation 86, 803-11.

Satchell, L. \& Leake, D. S., 2012. Oxidation of low-density lipoprotein by iron at lysosomal pH: implications for atherosclerosis. Biochemistry 51, 3767-75.

Smith, C., Mitchinson, M. J., Aruoma, O. I. \& Halliwell, B., 1992. Stimulation of lipid peroxidation and hydroxy-radical generation by the contents of human atherosclerotic lesions. Biochem. J. 286, 901-905.

Sofuni, T., Matsuoka, A., Sawada, M., Ishidate, M., Zeiger, E. \& Shelby, M. D., 1990. A comparison of chromosome aberration induction by 25 compounds tested by 2 Chinese hamster-cell (CHL and $\mathrm{CHO}$ ) systems in culture. Mutat. Res. 241, 175-213.

Sparrow, C. P., Doebber, T. W., Olszewski, J., Wu, M. S., Ventre, J., Stevens, K. A. \& Chao, Y. S., 1992. Low-density lipoprotein is protected from oxidation and the progression of atherosclerosis is slowed in cholesterol-ded rabbits by the antioxidant N,N'-diphenyl-phenylenediamine. J. Clin. Invest. 89, 1885-1891.

Steinberg, D., 2009. The LDL modification hypothesis of atherogenesis: an update. J. Lipid Res 50, S376-S381.

Steinbrecher, U. P., Parthasarathy, S., Leake, D. S., Witztum, J. L. \& Steinberg, D., 1984. Modification of low density lipoprotein by endothelial cells involves lipid peroxidation and degradation of low density lipoprotein phospholipids. Proc. Natl. Acad. Sci. U. S. A. 81, 3883-3887.

Sullivan, J. L., 1981. Iron and the sex difference in heart-disease risk. Lancet 1, 1293-1294.

Tang, L. X., Zhang, Y., Qian, Z. M. \& Shen, X., 2000. The mechanism of Fe ${ }^{2+}$-initiated lipid peroxidation in liposomes: the dual function of ferrous ions, the roles of the pre-existing lipid peroxides and the lipid peroxyl radical. Biochem. J. 352, 27-36.

Tangirala, R. K., Casanada, F., Miller, E., Witztum, J. L., Steinberg, D. \& Palinski, W., 1995. Effect of the antioxidant $\mathrm{N}, \mathrm{N}$-diphenyl 1,4-phenylenediamine (DPPD) on atherosclerosis in apoEdeficient mice. Arterioscler. Thromb. Vasc. Biol. 15, 1625-1630.

Theil, E. C., 1987. Ferritin - Structure, gene-regulation, and cellular function in animals, plants, and microorganisms. Annu. Rev. Biochem. 56, 289-315.

Ueda, M., O'brien, K., Rosing, D. R., Ling, A., Kleta, R., Mcareavey, D., Bernardini, I. \& Gahl, W. A., 2006. Coronary artery and other vascular calcifications in patients with cystinosis after kidney transplantation. Clin. J. Am. Soc. Nephrol. 1, 555-562.

Van Reyk, D. M., Brown, A. J., Jessup, W. \& Dean, R. T., 1995. Batch-to-batch variation of Chelex-100 confounds metal-catalyzed oxidation, leaching of inhibitory compounds from a batch of Chelex-100 and their removal by a pre-washing procedure. Free Radic. Res. 23, 533-535.

Wen, Y. \& Leake, D. S., 2007. Low density lipoprotein undergoes oxidation within lysosomes in cells. Circ. Res. 100, 1337-1343.

Wilcox, C. S. \& Pearlman, A., 2008. Chemistry and antihypertensive effects of tempol and other nitroxides. Pharmacol. Rev. 60, 418-469.

Wilkins, G. M. \& Leake, D. S., 1994. The effect of inhibitors of free radical generating-enzymes on low-density lipoprotein oxidation by macrophages. Biochim. Biophys. Acta 1211, 69-78.

You, S. A., Archacki, S. R., Angheloiu, G., Moravec, C. S., Rao, S. Q., Kinter, M., Topol, E. J. \& Wang, Q., 2003. Proteomic approach to coronary atherosclerosis shows ferritin light chain as a significant marker: evidence consistent with iron hypothesis in atherosclerosis. Physiol. Genomics 13, 25-30.

Yuan, X. M., 1999. Apoptotic macrophage-derived foam cells of human atheromas are rich in iron and ferritin, suggesting iron-catalysed reactions to be involved in apoptosis. Free Radic. Res. 30, 221-235. 
Yuan, X. M., Li, W., Olsson, A. G. \& Brunk, U. T., 1996. Iron in human atheroma and LDL oxidation by macrophages following erythrophagocytosis. Atherosclerosis 124, 61-73. 